食道癌術後高ビリルビン血症症例の検討

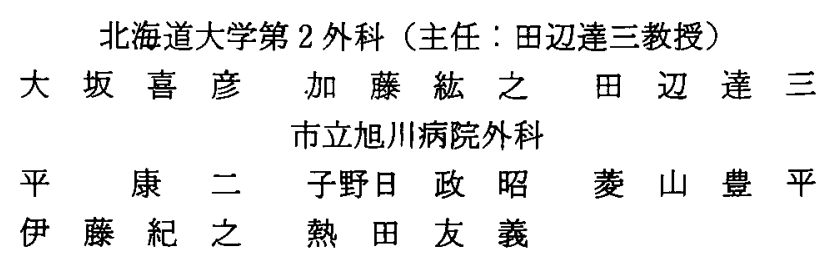

胸部食道癌切除術後には高頻度に高ビリルビン血症が出現することが指摘されてい る.今回われわれは術後高ビリルビン血症の発生状況および発生に関与する因子につい て，(1)食道癌切除58症例，(2)胃癌胃全摘18症例, (3)直腸癌直腸切除むしくは切断の16症 例を対象に各種の要因について険討した。各症例群に拈ける術後高ビリルビン血症（総 ビリルビン>2.0)の発生率は，(1) $48.28 \%$, (2) $38.46 \%$, (3) $0 \%$ \%あり，食道癌切除後の 高ビリルビン血症の発生率は直腸切除もしくは切断後に比べ有意に高かったが胃全摘後 とは有意差は認められなかった。また食道癌切除後の高ビリルビン血症の発生群と非発 生群との間では術前・術中・術後の各因子に関して 2 群間に有意差は認められなかった。 今回の検討では高ビリルビン血症の発生要因を単一化して明確にすることはできず，食 道切除後の高ビリルビン血症は多くの要因が複合し発生するもので, 単一の因子による ものではないと考えられた。

索引用語：胸部食道癌, 食道癌手術, 食道癌術後合併症, 高ビリルビン血症

はじめに

ある種の手術後には高頻度に高ビリルビン血症が出 現し, とりわけ胸部食道癌切除術後では有意に発生率 が高いと言われている。この高ビリルビン血症の多く は術後急性期をすぎると改善し必ずしも救命的合併症 とはならない。しかしその発生病態についてはこれま で十分に検討されておらず，したがってその対策も立 てられていないのが現状である，今回われわれは食道 癌切除術後の高ビリルビン血症の発生状況お上び発生 に関与する因子について検討し，あわせて若干の文献 的考察を加壳たので報告する.

\section{症例と検索方法}

対象は，昭和56年 5 月より昭和63年 6 月までの間に 切除を行った食道癌症例のらち, 術前より肝機能障害 の認められた症例および肝胆道系の合併切除を行った 症例をのぞく58症例である．対照群として昭和61年 6 月より昭和62年12月までの間に行った胃全摘症例で同 上の条件をみたす 18 症例，および昭和 61 年 6 月より昭

1989年11月22日受付 1990 年 7 月16日採用
和62年12月までの間に行った直腸切除もしくは切断症 例で同上の条件をみたす16症例とした。術後に一度で も血清総ビリルビン值が $2.0 \mathrm{mg} / \mathrm{dl}$ 以上となった症例 を高ビリルビン血症症例とし，その観察期間は術後 1 カ月間とした。 これらの症例につき，年龄，性別，術 式, 術前の化学療法・放射線療法・中心静脈栄養法の 施行の有無および糖尿病の合併の有無, 術前・術後の 臨床検査成績, 手術時間, 術中出血量, 縫合不全 - 衍 後肺合併症の有無と高ビリルビン血症との相関関係を 調べた。

なお合併症の定義は以下のように定めた。

1）縫合不全：臨床症状および造影検査で絴合不全 の認められたもの（造影上の mimorleakage 含め る).

2）肺合併症：臨床的に肺炎の認められたもの,また 気管チューブ拔管後呼吸状態が悪化し再插管を行った もの.

統計上の有意差検定にはY Yates の修正による $\chi^{2}$ 検 定および normal distributionを用いた。相関係数は Spearmanの順位差の方法を用いて算出し，その検定 
には F 分布による検定を行った。いずれる有意水準は $5 \%$ とた。

\section{結果}

\section{1）術式別の高ビリルビン血症発生率}

食道癌切除後の高ビリルビン血症発生率は $48 \%$ $(n=58)$ 胃全摘術後の発生率は28\% $(n=18)$ 直腸切除 むしくは切断術後の発生率は $0 \%(n=16)$ である，食 道癌切除後の発生率は直腸切除むしくは切断術後の発 生率に比べ有意に高率であるが，胃全摘術後の発生率 とは統計学的有意差は認められなかった。

また食道癌切除群の肺合併症，䋖合不全，手術時間， 出血量, 総ビリルビン最高値は他の 2 群に比べ有意に 高かった（表 1 ）.

2）食道湆切除後の高ビリルビン血症発生群と高ビ リルビン血症非発生群の比較

食道癌術後例を高ビリルビン血症発生群と高ビリル ビン血症非発生群の 2 群に分け術前・術中・術後の各 因子について検討した，平均年龄は高ビリルビン血症 発生群66.4歳, 高ビリルビン血症非発生群61.1歳. 血 清蛋白は各7.39g/dl, $7.14 \mathrm{~g} / \mathrm{dl}$ でともに有意差は認め られなかった。 また，手術時間，出血量，付加療法の 有無，艇合不全，糖疗病合併などです 2 群間に差は認 められず，むしろ高ビリルビン血症非発生例で高頻度 に認められた因子もあった。なお肺合併症は高ビリル ビン血症発生例に多く認められた（表 2 ）.

3）術前状態と高ピリルピン血症の発生

術前放射線療法, 術前化学療法, 術前中心静脈栄養, 扣よび糖尿病合併の有無による高ビリルビン血症発生

表 1 術式別の高ビリルビン血症発生わよひ諸因子

\begin{tabular}{|c|c|c|c|}
\hline & 食道切除 & 胃全摘 & $\begin{array}{l}\text { 直腸切除. } \\
\text { 切断 }\end{array}$ \\
\hline 全应例数 & 58 & 18 & 16 \\
\hline 平均年龄 (歳) & 63.50 & 63.83 & 65.88 \\
\hline 高ビ血症発生例数 & 28 & 5 & 0 \\
\hline 高ビ血症発生\% & 48.28 & 27.78 & 0 \\
\hline 肺合併症発生例数 & 19 & 0 & 1 \\
\hline 䋖合不全発生例数 & 12 & 0 & I \\
\hline 平均手術時間（分） & 495.65 & 344.72 & 232.19 \\
\hline 平均出血量 $(\mathrm{ml})$ & 1172.54 & 880.56 & 656.25 \\
\hline $\mathrm{TB}$ 最高値平均 (mg/dl) & 3.51 & 1.79 & 0.90 \\
\hline $\begin{array}{l}\text { TB が最高値を } \\
\text { 示した日の平均 (日) }\end{array}$ & 5.19 & 3.94 & 3.63 \\
\hline
\end{tabular}

食道切除 ; 食道癌切除症例，胃全摘 ; 胃癌胃全摘症例

直腸切除・切断；直腸癌直腸切除・切断症例

高ビ血症；高ビリルビン血症，TB；血中総ビリルビン值
率の差はいずれの因子についても認められなかった （表 3).

4）手術侵襲と高ビリルビン血症発生

高ビリルビン血症発生群において総ビリルビン最高 値と出血量の関係および，総ビリルビン最高檤と手術 時間の関係につき検討した。相関係数は各一0.183, 0.240 と有意な相関は認められなかった（図 1 ）.

\section{5）術後合併症と高ビリルビン血症の発生}

術後合併症の有無と高ビリルビン血症発生率をみる と肺合併症を起こした症例では高ビリルビン血症を発 生する例が多く $(68 \%)$ ，一方縫合不全を起こした症例 では高ビリルビン血症の発生例は少なかった（37\%）。 しかしこれらの要因は，いずれも有意な発生率の差は 示さなかった（表 4 ）。

\section{考察}

文献的に術後高ビリルビン血症の発生頻度をみると Evans ら 11 は各種術後症例の $20.2 \% に$ 血清ビリルビン 伯の上昇 (T. Bil $>1.5 \mathrm{mg} / \mathrm{dl}$ ) を認め Geller ら²腹 部手術症例の $72 \%$ にビリルビン上昇を認めたと報告し ている. Morgenstern ら゙は15年間に1,000例の高ビリ ルビン血症（T. Bil >2.5mg/dl）を認めており，各種 手術後に高頻度に高ビリルビン血症が出現することを 示している。一方食道癌手術に注目してみると, 北村

\section{表 2 食道癌切除後高ビリルビン血症発生群と} 非発生群の諸因子

\begin{tabular}{|c|c|c|}
\hline & $\begin{array}{l}\text { 高ビ血症 } \\
\text { 発生群 }\end{array}$ & $\begin{array}{l}\text { 高ビ血症 } \\
\text { 非発生群 }\end{array}$ \\
\hline 应 例 数 & 28 & 30 \\
\hline TB 最高值平均 (mg/dl) & 5.20 & 1.24 \\
\hline $\mathrm{DB}$ 最高値平均 $(\mathrm{mg} / \mathrm{dl})$ & 3.19 & 0.65 \\
\hline $\begin{array}{l}\text { TB が最高値を示した日の平均（日） } \\
\text { (術前因子) }\end{array}$ & 6.93 & 3.57 \\
\hline  & 66.04 & 61.13 \\
\hline $\mathrm{DM}$ 合併例数 & 1 & 2 \\
\hline 術前 IVH 施行例数 & 16 & 18 \\
\hline 術前放射線療法施行例数 & 4 & 3 \\
\hline 術前化学撩法施行例数 & 5 & 0 \\
\hline 術前総蛋白平均 $(\mathrm{g} / \mathrm{dl})$ & 7.39 & 7.14 \\
\hline (術中因子) & & \\
\hline 平均手術時間（分） & 431.43 & 486.89 \\
\hline 平均出血量 (ml) & 1132.68 & 1238.62 \\
\hline （術後因子） & & \\
\hline 肺合併㱏発生例数 & 13 & 6 \\
\hline 縫合不全発生例数 & 4 & 8 \\
\hline
\end{tabular}

$\mathrm{DM}$; 糖永病, IVH ; 中心静脈栄坦

$\mathrm{DB} ;$ 血中直接ビリルビン值 
表 3 術前因子と術後高ビリルビン血症の発生

\begin{tabular}{|c|c|c|c|c|}
\hline & & \multicolumn{2}{|c|}{ 術前放射線療法 } & \multirow{2}{*}{ 計 } \\
\hline & & 施行 & 施行せず & \\
\hline \multirow{2}{*}{ 高ビ血症 } & 発 生 & 4 & 24 & 28 \\
\hline & 発生せず & 3 & 27 & 30 \\
\hline \multicolumn{2}{|c|}{ 計 } & 7 & 51 & 58 \\
\hline
\end{tabular}

\begin{tabular}{|c|c|c|c|c|}
\hline & \multicolumn{2}{|c|}{ 術前化学療法 } & \multirow{2}{*}{ 計 } \\
\hline & & 施行 & 施行せず & \\
\hline \multirow{2}{*}{ 高ビ血症 } & 発生 & 5 & 23 & 28 \\
\hline & 発生せず & 0 & 30 & 30 \\
\hline \multicolumn{2}{|c|}{ 計 } & 5 & 53 & 58 \\
\hline
\end{tabular}

\begin{tabular}{|c|c|c|c|c|}
\hline & & \multicolumn{2}{|c|}{ 術前 IVH } & \multirow{2}{*}{ 計 } \\
\hline & & 施行 & 施行せず & \\
\hline \multirow{2}{*}{ 高ビ血症 } & 発 生 & 16 & 12 & 28 \\
\hline & 発生せず & 18 & 12 & 30 \\
\hline \multicolumn{2}{|c|}{ 計 } & 34 & 24 & 58 \\
\hline
\end{tabular}

\begin{tabular}{|c|c|c|c|c|}
\hline & & \multicolumn{2}{|c|}{ DM 合併 } & \multirow{2}{*}{ 計 } \\
\hline & & あり & なL & \\
\hline \multirow{2}{*}{ 高ビ血症 } & 発 生 & 1 & 27 & 28 \\
\hline & 発生せず & 2 & 28 & 30 \\
\hline \multicolumn{2}{|c|}{ 計 } & 3 & 55 & 58 \\
\hline
\end{tabular}
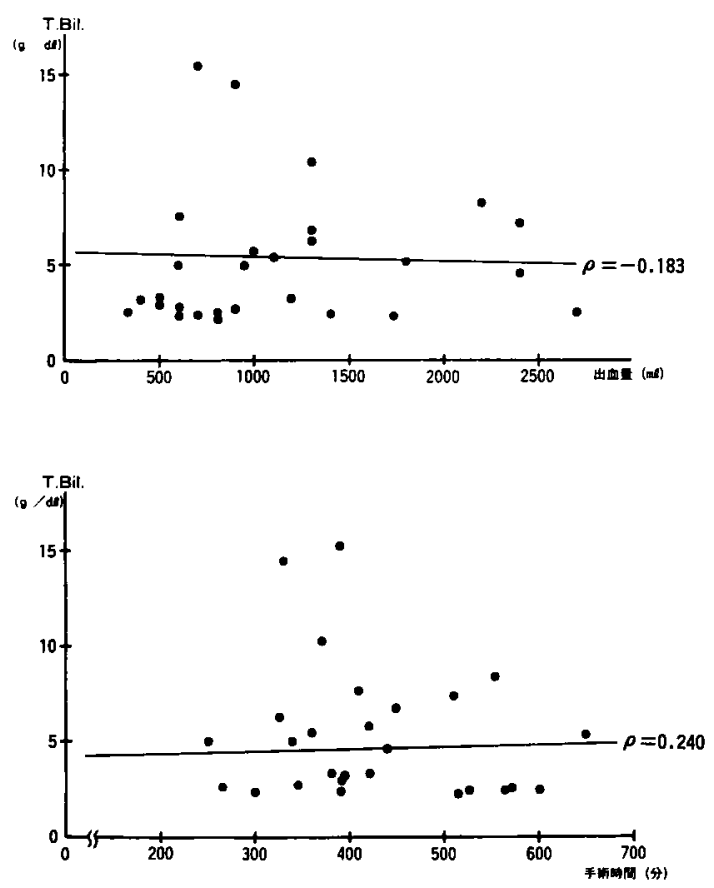

図 1 総ビリルビン最高优と出血量および手術時間の 相関

ら4の報告では胸部食道癌切除後の $60.8 \%$ に高ビリル ビン血症 (T.Bil $\geqq 2.0 \mathrm{mg} / \mathrm{dl}$ ) が出現しており, 辻仲 ら5は食道癌切除後の $59 \%$ に発生したと報告してい る.また辻仲ら ${ }^{5)}$ の報告では，胃全摘術後に $28 \%$ ，結腸 切除後に $12 \%$ の高ビリルビン血症 (T. Bil $\geqq 2.0 \mathrm{mg} / \mathrm{dl}$ むしくは黄疸指数 115）が出現したが，これらは食道 癌切除後に比べ有意に発生率が低かった。今回の我々 の検討では食道癌切除後の高ビリルビン血症の発生率 は $48.3 \%$ 之比較的高率であった。この発生率は直腸切 除もしくは切断術後の発生率 $0 \%$ に比べ高率であった が，胃全摘術後の発生率 $38.5 \%$ とは有意差は認められ なかった。

術後高ビリルビン血症の発症要因を文献的に検討し てみると, ショック・敗血症・心不全等に起因する肝 細胞障害によるもの ${ }^{1 / 6) 7}$, 高カロリー輸液が関与する もの ${ }^{588) 9}$, 輸血・溶血等によるビリルビンの過㮃負荷に よるすの尚(10)などの報告がある。これらの原因を LaMont ら ${ }^{11}$ は, 1）ビリルビンの負荷の過鄱, 2) 肝細 胞機能の低下(1)肝炎類似型と, (2)胆汁亏っ滞型)，3） 肝外性閉塞に大別し，さらに細分類している。しかし 食道癌切除術後高ビリルビン血症の発症にはこれらの

表 4 術啳合併症と術後高ビリルビン血症の発生

\begin{tabular}{|c|c|c|c|c|}
\hline & & \multicolumn{2}{|c|}{ 術後肺合併症 } & \multirow{2}{*}{ 計 } \\
\hline & & あり & なし & \\
\hline \multirow{2}{*}{ 高ビ血症 } & 発 生 & 13 & 15 & 28 \\
\hline & 発生せず & 6 & 24 & 30 \\
\hline \multicolumn{2}{|c|}{ 計 } & 19 & 39 & 58 \\
\hline
\end{tabular}

\begin{tabular}{|c|c|c|c|c|}
\hline & \multicolumn{2}{|c|}{ 術後䋖合不全 } & \multirow{2}{*}{ 計 } \\
\hline & & あり & なし & \\
\hline \multirow{2}{*}{ 高ビ血症 } & 発 生 & 4 & 24 & 28 \\
\hline & 発生せず & 8 & 22 & 30 \\
\hline \multicolumn{2}{|c|}{ 計 } & 12 & 46 & 58 \\
\hline
\end{tabular}


他に，多数の要素が関与して括り，より多くの要因を 考慮する必要がある。この点につき，北村ら4は術後 1 週間前後に高ビリルビン血症を認める症例はSchmid が報告した ${ }^{12)}$ benign postoperative intrahepatic cholestasis の範畴に入り, LaMont $ら^{11} の$ 分類の, 2) 肝細胞機能の低下の細項目の(3)としてこれを加えるこ とを提唱している。

高カロリー輸夜が胆汁うっ滞の原因となるとの報 告(3) 19) は多く、さらにこれが高ビリルビン血症発症と 関連している可能性があるとの報告5)(8)9) むる。 しか し我々の検討では術前の高カロリー輸液の有無と高ビ リルビン血症発症との間には有意の関係は認められな かった，食道癌切除術後は全例に対して高カロリー輸 液を行っているが，同様に高カロリー輸液を行ってい る直腸切除もしくは切断術後の高ビリルビン血症発生 率に比べ食道癌切除術後の高ビリルビン血症発生率は 有意に高率である，そのため高カロリー輸液自体が高 ビリルビン血症の原因であるとは考えにくく，过仲 ら゙が指摘しているように高カロリ一輸液施行時にさ らに何らかの誘因が加わり高ビリルビン血症が発生す る可能性が考劣られた。

感染症が高ビリルビン血症発症の原因になるとの報 告20121)またエンドトキシンが胆汁うっ滞の原因となる との報告 ${ }^{22}$ 向ある。しかし食道癌切除術後の白血球増 多の程度と高ビリルビン血症の程度との間には有意の 関俰は認められず，また術後の肺合併症および絴合不 全と高ビリルビン血症発症との間にも有意の関俰は認 められなかった。

手術侵齱自体による影響も高ビリルビン血症発症の

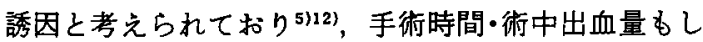
くは輸血量と高ビリルビン血症発症との間に有意の関 係を認めた報告45) あある，今回のわれわれの検討で は，手術時間・術中出血量の両者が食道癌切除術に拉 いて胃全摘術より有意に大であり，また高ビリルビン 血症の程度む有意に高かった。しかしながら食道癌切 除後症例のみについて手術時間・術中出血量と血清ビ リルビン値の関係につき検討しても有意の相関関係は 認めら机なかった．したがって高ビリルビン血症発生 の誘因の一つとして手術時間・術中出血量もしくは輸 血量が関与していると考えられるが，各々が単独で高 ビリルビン血症発生の原因となるとは考皇にくいと思 われる。

これまで胃癌切除後の胆垔炎や胆石症の発生につい ては多くの報告があり，その原因の一つとして手術時
の迷走神経切断があげられている，食道癌切除後にむ 胆爱収縮能の低下などを生じ胆汁うっ滞が認められる との報告もあり ${ }^{23)}$, 高ビリルビン血症発生の原因とし てこの迷走神経切断が関与していることる否定できな いわれわれの検討では高ビリルビン血症の発生率が 食道癌切除後は直腸切除もしくは切断術後に比べ有意 に高率であったが，胃全摘術後とは有意差は認められ なかった。

以上今回の検討では高ビリルビン血症の発生要因を 単一化して明確にすることはできなかったが，食道癌 切除術時の迷走神経切断に上る胆票収緶能の低下など で胆汁うっ滞が生じたところに高カロリ一輸液による 影響が加わる例，あるいは輸血・焀血等によるビリル ビンの過剰負荷，感染症による影響，手術侵襲自体に よる影響など，多くの要因が個々の症例に加わりこの ような高ビリルビン血症が発生したものと推測され た.

\section{結 語}

1）食道切除・胃全摘・直腸切除るしくは切断の各症 例群に対し術後高ビリルビン血症の発生に注目して各 種の要因を検討した。

2）食道切除・胃全摘・直腸切除もしくは切断の各症 例群における術後高ビリルビン血症の発生率は各 $48.28 \% ， 38.46 \% ， 0 \% て ゙ あ り ，$ 食道切除後の高ビり ルビン血症の発生率は直腸切除もしくは切断後に比べ 有意に高かったが胃全摘後とは有意差は認められな かった。

3）食道切除後の高ビリルビン血症の発生群と非発 生群との間では術前・術中・術後の各因子に有意差は 認められなかった。

4）食道切除後の高ビリルビン血症の発生群におい て血清総ビリルビンの最高值と手術時間もしくは出血 量との間には有意な相関関係は認められなかった。

5）食道切除後の高ビリルビン血症は多くの要因が 複合し発生するもので，単一の因子によるすのではな いかと考えられた。

本論文の要旨は第49回北海道外科学会 (1988年 9 月 10 日, 札幌，田辺達三会長）において発表した。

\section{文献}

1) Evans C, Evans M, Pollock AV: The incidence and causes of postoperative jaundice. $\mathrm{Br}$ J Anaesth 46:520-525, 1974

2) Geller W, Tognon $\mathrm{HJ}$ : Liver dysfunction fol low abdominal operations. Arch Inter Med 86 
908-916, 1950

3) Morgenstern L: Postoperative jaundice, an approach to a diagnotic dilemma. Am J Surg 128: 255-261, 1974

4) 北村道彦, 西平哲郎, 平山 克他：食道癌術後の高 ビリルビン血症の検討，日消外会誌 21：2063 $-2068,1988$

5）过仲利政,城戸良弘, 小川塞誉他：食道癌切除術後 の高ビリルビン血症の検討, 日外会誌 88：939 -946, 1987

6) Kantrowitz PA, Jone WA, Greenberger NJ, et al: Sever postoperative hyperbilirubinemia simulating obstructive jaundice. N Engl J Med 276 : 591-598, 1967

7) 大星章一, 大星幸雄, 片桐 一他：術後急性肝督障 害一 6 例の臨床病理学的検討とその対策, 医のあ 中及 $68: 172-181,1969$

8) Ginn-Peace ME, Pantalos D, King DR: TPNassociated hyperbilirubinemia: A Common problem in newborn surgical patient. J Pediatr Surg $20: 436-439,1985$

9）落田昭男, 根津理一郎, 鎌田振吉他：新生児高カ口 リー輸夜に括ける黄疸発生一過去12年間における 教室例の臨床的検討, 日外会誌 87：162-171, 1986

10) Schalm L, Weber AP: Jaundice with conjugated bilirubin in hyperhaemolysis. Acta Med Scand 176: 549-553, 1964

11) Lamont JT, Isselbacher $\mathrm{KJ}$ : Post operative jaundice. N Engl J Med 288 : 305-307, 1973

12) Schmid M, Hefti ML, Gattiker $R$, et al: Benign postoperative intrahepatic cholestersis. N Engl J Med 272 : 545-550, 1965

13) Black DD, Suttle EA, Whitington PF, et al: The effect of short-term total parental nutrition on hepatic function in the human neonate: A prospective randmized study demonstrating alteration of hepatic canalicular function. J
Pediatr 99 : 445-449, 1981

14) Nanji AA, Anderson FH: Relationship between serum albumin and parental nutrition associated cholestersis. J Parenteral Enteral Nutr $8: 438-439,1984$

15) Fouin-Founet $H$, Quernec LL, Erlinger $S$, et al: Hepatic alternations during total parental nutrition to pations with inframmatory bowel disease : A possible consequence of lithocholate toxicity. Gastroenterology 82 : 932-937, 1982.

16) Cooper A, Betts JM, Pereira GR, et al: Taurine dficiency in the sever hepatic dysfunction complicating total parental nutrition. J Pediatr Surg $19: 462-466,1984$

17) Latham PS, Menkes E, Philips MJ, et al: Hyperalimentation-associated jaundice: An example of a serum factor inducing cholestersis in rats. Am J Clin Nurt $41: 61-65,1985$

18) Touloukian RJ, Seashore JH: Hepatic secretory obstruction with total parental nutrition in the infant. J Pediatr Surg $10: 353-360,1975$

19) Podgers BM, Hollenbeck JI, Donnery WH, et al: Intrahepatic cholestersis with parental alimentation. Am J Surg 131 : 149-155, 1976

20) Miller DJ, Keeton GR, Webber BL, et al: Jaundice in sever bacterial infection. Gastroenteology 71 : 94-97, 1976

21) Zimmerman HJ, Fang M, Utili R, et al: Jaundice due to bacterial infection. Gastroenteology 77 : 362-374, 1979

22) Utili $\mathrm{R}$, Abernathy $\mathrm{CO}$, Zimmerman $\mathrm{HJ}$ : Inhibition of $\mathrm{Na}^{+}, \mathrm{K}^{+}$Adenosinetriphosphatase by endotoxin: A possible mechanism for endotoxin-induced cholestersis. $J$ Infect Dis $136: 583-587,1977$

23）延澤 進, 遠藤光夫: 食道癌衍後早期におけりる胆 计万っ滞と胆衰収縮能の検討, 日臨外医会誌 48 : $574-583,1987$ 


\title{
A STUDY OF POSTOPERATIVE JANUDICE IN PATIENTS WITH ESOPHAGEAL CANCER
}

\author{
Yoshihiko OHSAKA, Koji TAIRA*, Masaaki NENOHI*, Houhei HISHIYAMA*, Noriyuki ITO*, \\ Tomoyoshi ATSUTA*, Hiroyuki KATO and Tatsuzo TANABE \\ Second Department of Surgery, Hokkaido University, School of Medicine \\ *Department of Surgery, Municipal Asahikawa Hospital
}

It is known that hyperbilirubinemia often occurs after operation for esophageal cancers. We studied the occurrence of postopertive jaundice and risk factors participating in the occurrence in 1) 58 patients with esophageal cancer; 2) 18 with gastric cancer; and 3) 16 with rectal cancer. The incidence of postoperative jaundice (total bilirubin $\geqq 2.0 \mathrm{mg} / \mathrm{dl}$ ) was $48.28 \%, 38.46 \%$, or $0 \%$ in patients group 1), 2 ), or 3 ), respectively. The incidence in group 1) was significantly higher than that in group 3 ), but was not significantly differ from that in group 2).

No significant difference in risk factors before, during after surgery was found between two patients groups with or without jaundice. From these findings, no single risk factor for postoperative jaundice could be identified. It is presumed that not only one but many complicated factors are involved in the development of jaundice following excision of esophagus. 